\title{
Binary Mixtures of Morphine and Furosemide: Compatibility and Stability at Different Concentrations
}

\author{
Espinosa Bosch María1, Sánchez Rojas Fuensanta ${ }^{2 *}$, Bosch Ojeda Catalina ${ }^{2}$ \\ 1UGC Pharmacy, Regional Universitary Hospital of Málaga, 29010, Málaga, Spain. \\ ${ }^{2}$ Department of Analytical Chemistry, Faculty of Sciences, University of Málaga, Spain.
}

\begin{abstract}
Objectives: In order to avoid separate injections, admixtures of drugs are frequently used in palliative care settings. There are different factors that can influence the compatibility and stability of the mixture: drug type, concentration, solvent, container, temperature and light. There are some mixtures of drugs with proven stability, but there is lack of evidence about the stability and compatibility of the combination of morphine and furosemide. The purpose is to evaluate the compatibility and stability of two admixtures of morphine and furosemide at two different temperatures $\left(25^{\circ} \mathrm{C}\right.$ and $\left.37^{\circ} \mathrm{C}\right)$. The concentrations of the admixtures are: $3.0 \mathrm{mg} / \mathrm{mL}-2.0 \mathrm{mg} / \mathrm{mL} ; 1.0 \mathrm{mg} / \mathrm{mL}-0.6 \mathrm{mg} / \mathrm{mL}$; in $\mathrm{NaCl} 0.9 \%$ stored in elastomeric infusors protected from light. Methods: The samples were prepared and diluted in $\mathrm{NaCl} 0.9 \%$ in elastomeric infusor in triplicate to obtain four different conditions of concentration and/or temperature of storage (concentration: $3.0 \mathrm{mg} / \mathrm{mL}-2.0 \mathrm{mg} / \mathrm{mL}$, $1.0 \mathrm{mg} / \mathrm{mL}-0.6 \mathrm{mg} / \mathrm{mL}$ of morphine and furosemide respectively; temperature of storage $25^{\circ} \mathrm{C}$ and $37^{\circ} \mathrm{C}$ ). The concentration of each constituent drug into different mixtures was periodically determined using a HPLC-UV method. The drugs were chromatographed on a $C_{18}$ reverse phase column; the mobile phase was acetonitrile-water 40:60 (v/v); flow rate $1.5 \mathrm{~mL} / \mathrm{min}$. Morphine and furosemide concentrations were determined at $235 \mathrm{~nm}$ by interpolation from the calibration curves prepared at $(0,1,2,3,7,8,9,10,14,15)$ days from the standards. Statgraphics centurion XVI program has been used to data treatment. Results: The stability of the admixtures diluted in $\mathrm{NaCl} 0.9 \%$ are as follow: morphine-furosemide $(3.0 \mathrm{mg} / \mathrm{mL}-2.0 \mathrm{mg} / \mathrm{mL}$ ) is stable (retained $>95 \%$ of their initial concentration) eight days at $25^{\circ} \mathrm{C}$ and two day at $37^{\circ} \mathrm{C} ;(1.0 \mathrm{mg} / \mathrm{mL}-0.6 \mathrm{mg} / \mathrm{mL})$ is stable thirty days at $25^{\circ} \mathrm{C}$ and two day at $37^{\circ} \mathrm{C}$. Conclusion: The admixture of morphine and furosemide in $\mathrm{NaCl} 0.9 \%$ in elastomeric infusor can be safely used in palliative care for at least two days. Concentrations of the admixture can be prepared in advance and stored at room temperature, but the infusion cannot be longer than two days.

Key words: Furosemide, HPLC, Mixtures, Morphine, Stability.
\end{abstract}

\section{INTRODUCTION}

The definition of the World Health Organization $(\mathrm{WHO})^{1}$ about palliative care is follow: an approach that improves the quality of life of patients and their families facing the problem associated with life-threatening illness, through the prevention and relief of suffering by means of early identification and impeccable assessment and treatment of pain and other problems, physical, psychosocial and spiritual. Palliative care provides relief from pain and other distressing symptoms affirms life and regards dying as a normal process, intends neither to hasten or postpone death, integrates the psychological and spiritual aspects of patient care, offers a support system to help patients live
Submission Date : 03-06-2015 Revision Date : :29-01-2015 Accepted Date : :18-06-2015

DOI: $10.5530 /$ ijper.49.4s.9 Correspondence Address Mr. Fuensanta Sánchez Rojas

Department of Analytical Chemistry, Faculty of Sciences, University of Málaga, 29071 Málaga, Spain. E-mail:fsanchezr@uma.es

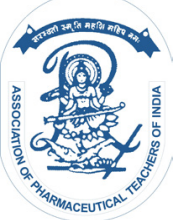

www.ijper.org 


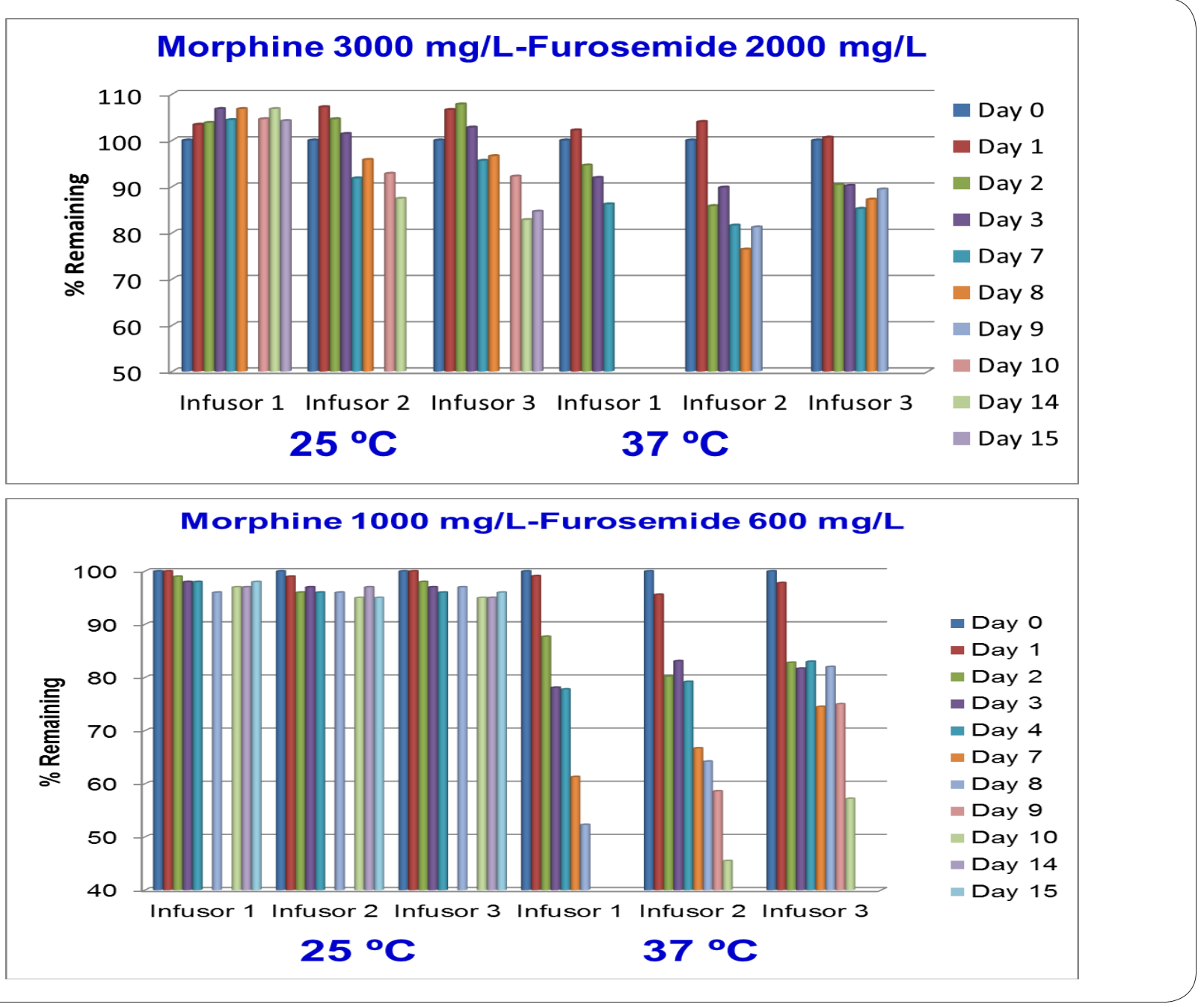

\section{Graphical abstract}

as actively as possible until death, offers a support system to help the family cope during the patients illness and in their own bereavement, uses a team approach to address the needs of patients and their families, including bereavement counselling, if indicated, will enhance quality of life, and may also positively influence the course of illness, is applicable early in the course of illness, in conjunction with other therapies that are intended to prolong life, such as chemotherapy or radiation therapy, and includes those investigations needed to better understand and manage distressing clinical complications.

To obtain optimal symptom control in these patients, the simultaneous administration of more than one drug is often required. ${ }^{2}$

When the oral administration of drugs is no longer possible at a later stage of the disease because symptoms worsen and the patient's general condition deteriorates, alternative methods of delivering the drugs may be necessary. The ideal system should deliver the drug reliably in a pain-free manner, use a minimum amount of nurs- ing time and allow the patient remain mobile. In addition, it should be simple to use and not too costly. ${ }^{3}$

To avoid the use of different infusion needles, it may be beneficial to mix different drugs in one single infuser. Drug infusers offer the possibility of continuous subcutaneous drug administration that, compared to intermittent injections, gives a more constant plasma concentration. The continuous subcutaneous infusion of drugs has become an accepted practice, especially in the palliative care of cancer patients, in the 20 years. ${ }^{4-6}$ The patients tolerate the treatment well, and infusionsite infection and abscess are rare.

Morphine is an opioid analgesic used for the treatment of moderate to severe pain. It is recommended by the WHO for the relief of moderate cancer-related pain. It is the opioid of choice in palliative and terminal care. Morphine is predominantly cleared from body by metabolism to morphine-3-glucuronide (M3G) and morphine-6-glucuronide (M6G). Furosemide is a loop diuretic, which is an anthranilic acid derivative (5-(aminosulfonyl)-4-chloro-2-[(2-furanylmethyl)amino] 
benzoic acid) used in the treatment of congestive heart failure and edema. His medication is also used to treat high blood pressure (hypertension). Furosemide works by blocking the absorption of salt and fluid in the kidney tubules, causing a profound increase in urine output (diuresis). The diuretic effect of furosemide can cause body water and electrolyte depletion. Therefore, careful medical supervision is necessary during treatment.

The physical compatibility and/or stability of several drugs in solution destined to subcutaneous infusion has been widely studied, ${ }^{7-11}$ although in some studies only visual inspection of the samples was performed, providing information on the physical compatibility but not on the chemical stability of the drugs in the mixture. Moreover, studies have not yet been done regarding the combination of morphine and furosemide in solution in which the quantification of both drugs was performed by HPLC. On the other hand, patients will only benefit from the use of mixtures if those mixtures are of good quality since the administration of incompatible mixtures could cause irritation. Besides, chemical incompatibility and instability of the drugs in the mixture will result in an inadequate therapeutic outcome, and the degradation products may cause additional side effects.

Therefore, the aim of this study was to determine the compatibility and stability of morphine and furosemide combined in solution at two different concentrations and stored in elastomeric infusors protected from light at $25^{\circ} \mathrm{C}$ and $37^{\circ} \mathrm{C}$ over a period of 15 days.

\section{MATERIAL AND METHODS}

\section{Materials}

Commercial morphine ampoules of $20 \mathrm{mg} / \mathrm{mL}$ (Morphine, Braun, Spain) and commercial furosemide ampoules of $20 \mathrm{mg} / 2 \mathrm{~mL}$ (Furosemide, Fresenius Kabi, Spain) were used. Sodium chloride $0.9 \%$ was obtained from Fresenius Kabi, Spain. HPLC-grade acetonitrile was obtained from Sigma-Aldrich. Other chemical and solvents were of analytical grade and obtained from Sigma-Aldrich, Germany. High purity water (resistivity $18.2 \mathrm{M} \Omega \mathrm{cm}$ ) obtained by a Milli-Q water purification system (Millipore, Bedford, MA, USA) was used throughout this work.

\section{Drug mixtures}

The doses of morphine and furosemide assayed in the study were chosen taking into consideration those more frequently used by the units of palliative care in our region. The doses assayed were $3.0 \mathrm{mg} / \mathrm{mL}-2.0 \mathrm{mg} / \mathrm{mL}$ and $1.0 \mathrm{mg} / \mathrm{mL}-0.6 \mathrm{mg} / \mathrm{mL}$ of morphine and furosemide respectively, which were prepared in $0.9 \%$ normal saline for injection and stored at two temperatures, $25^{\circ} \mathrm{C}$ and $37^{\circ} \mathrm{C}$ each one, employing a bacteriological and culture oven with temperature and time regulation and digital reading, Selecta (INCUDIGIT 19L 2001246). Each of these four alternatives were prepared in triplicate in elastomeric infuser and protected from light and also in glass. From each mixture, five standards of different concentrations between $25 \mathrm{mg} / \mathrm{mL}$ and $160 \mathrm{mg} / \mathrm{mL}$ of admixture were prepared. The standards were divided into different

\begin{tabular}{|c|c|c|c|c|c|c|c|}
\hline \multicolumn{8}{|c|}{ Morphine 3000 mg/L-Furosemide 2000 mg/L } \\
\hline \multirow{2}{*}{$\begin{array}{l}\text { Mixture } \\
\text { (mg/L) }\end{array}$} & \multirow{2}{*}{ Mean (mAU) } & \multirow{2}{*}{$\begin{array}{c}\text { Standard } \\
\text { deviation(mAU) }\end{array}$} & \multirow{2}{*}{$\begin{array}{c}\text { Variation } \\
\text { co-efficient (\%) }\end{array}$} & \multirow{2}{*}{$\begin{array}{l}\text { Minimum } \\
(\mathrm{mAU})\end{array}$} & \multirow{2}{*}{$\begin{array}{l}\text { Maximum } \\
(\mathrm{mAU})\end{array}$} & \multicolumn{2}{|c|}{ Confidence level (mAU) } \\
\hline & & & & & & Lower & Upper \\
\hline 25 & 401302 & 10328.2 & 2.5 & 384764 & 418392 & 388519 & 414085 \\
\hline 50 & 786610 & 17395.2 & 2.2 & 747382 & 816979 & 773827 & 799393 \\
\hline 75 & 1.16894E6 & 24395.0 & 2.1 & 1.13458E6 & 1.22736E6 & 1.15616E6 & 1.18172E6 \\
\hline 100 & 1.52877E6 & 45284.0 & 2.9 & 1.42979E6 & 1.57785E6 & $1.51598 \mathrm{E} 6$ & $1.54155 \mathrm{E} 6$ \\
\hline 125 & 1.96128E6 & 36051.1 & 1.8 & 1.87858E6 & 2.03426E6 & $1.9485 \mathrm{E} 6$ & 1.97406E6 \\
\hline \multicolumn{8}{|c|}{ Morphine $1000 \mathrm{mg} / \mathrm{L}-$ Furosemide $600 \mathrm{mg} / \mathrm{L}$} \\
\hline \multirow{2}{*}{$\begin{array}{l}\text { Mixture } \\
\text { (mg/L) }\end{array}$} & \multirow{2}{*}{ Mean (mAU) } & \multirow{2}{*}{$\begin{array}{c}\text { Standard } \\
\text { deviation (mAU) }\end{array}$} & \multirow{2}{*}{$\begin{array}{c}\text { Variation } \\
\text { co-efficient (\%) }\end{array}$} & \multirow{2}{*}{$\begin{array}{l}\text { Minimum } \\
(\mathrm{mAU})\end{array}$} & \multirow{2}{*}{$\begin{array}{l}\text { Maximum } \\
(\mathrm{mAU})\end{array}$} & \multicolumn{2}{|c|}{ Confidence level (mAU) } \\
\hline & & & & & & Lower & Upper \\
\hline 32 & 544266 & 26103.9 & 4.7 & 505872 & 594437 & 534662 & 553870 \\
\hline 64 & 972979 & 30031.7 & 3.0 & 920315 & 1.03607E6 & 963375 & 982583 \\
\hline 96 & 1.4587E6 & 38701.4 & 2.6 & 1.33988E6 & 1.53624E6 & 1.44909E6 & 1.4683E6 \\
\hline 128 & 1.92714E6 & 35780.5 & 1.8 & 1.86326E6 & 2.03565E6 & 1.91754E6 & 1.93674E6 \\
\hline 160 & $2.44182 \mathrm{E} 6$ & 36412.1 & 1.4 & 2.35097E6 & 2.53176E6 & 2.43221E6 & $2.45142 \mathrm{E} 6$ \\
\hline
\end{tabular}


Table 2: Concentrations obtained for the admixtures stored into infusors at $25^{\circ} \mathrm{C}$ and $37^{\circ} \mathrm{C}$

\begin{tabular}{|c|c|c|c|c|c|c|c|}
\hline \multicolumn{7}{|c|}{ [Admixture] $\pm \mathbf{S D}^{*}(\mathbf{m g} / \mathbf{L})(\mathbf{3 0 0 0} \mathbf{~ m g / L - 2 0 0 0 ~} \mathbf{~ m g / L )}$} \\
\hline Day & Inf 1 & Inf 2 & Inf 3 & Day & Inf 1 & Inf 2 & Inf 3 \\
\hline $\mathbf{0}$ & 50 & 50 & 50 & $\mathbf{0}$ & 50 & 50 & 50 \\
\hline $\mathbf{1}$ & $51.7 \pm 0.5$ & $53.6 \pm 0.5$ & $53.3 \pm 0.7$ & $\mathbf{1}$ & $51.1 \pm 0.4$ & $52.0 \pm 0.2$ & $50.3 \pm 0.7$ \\
\hline $\mathbf{2}$ & $51.9 \pm 0.3$ & $52.3 \pm 0.3$ & $53.9 \pm 0.3$ & $\mathbf{2}$ & $47.3 \pm 0.4$ & $42.9 \pm 0.5$ & $45.2 \pm 0.8$ \\
\hline $\mathbf{3}$ & $53.4 \pm 0.3$ & $50.7 \pm 0.8$ & $51.4 \pm 0.4$ & $\mathbf{3}$ & $45.9 \pm 0.8$ & $44.9 \pm 1.2$ & $45.1 \pm 0.4$ \\
\hline $\mathbf{7}$ & $52.2 \pm 0.3$ & $45.9 \pm 0.2$ & $47.8 \pm 0.4$ & $\mathbf{7}$ & $43.1 \pm 1.7$ & $40.8 \pm 0.4$ & $42.6 \pm 0.9$ \\
\hline $\mathbf{8}$ & $53.4 \pm 0.6$ & $47.9 \pm 0.1$ & $48.3 \pm 0.3$ & $\mathbf{8}$ & - & $38.2 \pm 1.5$ & $43.6 \pm 0.9$ \\
\hline $\mathbf{1 0}$ & $52.3 \pm 0.6$ & $46.4 \pm 1.5$ & $46.1 \pm 0.2$ & $\mathbf{9}$ & - & $40.6 \pm 0.6$ & $44.7 \pm 0.4$ \\
\hline $\mathbf{1 4}$ & $53.4 \pm 0.6$ & $43.7 \pm 0.3$ & $41.4 \pm 0.5$ & - & - & - & - \\
\hline $\mathbf{1 5}$ & $52.1 \pm 0.3$ & - & $42.3 \pm 0.4$ & - & - & - & - \\
\hline
\end{tabular}

Table 3: Concentrations obtained for the admixtures stored into infusors at $25^{\circ} \mathrm{C}$ and $37^{\circ} \mathrm{C}$

\begin{tabular}{|c|c|c|c|c|c|c|c|}
\hline \multicolumn{8}{|c|}{ [Admixture] $\pm \mathrm{SD}^{*}(\mathrm{mg} / \mathrm{L})(1000 \mathrm{mg} / \mathrm{L}-600 \mathrm{mg} / \mathrm{L})$} \\
\hline \multicolumn{4}{|c|}{$25^{\circ} \mathrm{C}$} & \multicolumn{4}{|c|}{$37^{\circ} \mathrm{C}$} \\
\hline Day & Inf 1 & Inf 2 & Inf 3 & Day & Inf 1 & Inf 2 & Inf 3 \\
\hline 0 & 64 & 64 & 64 & 0 & 64 & 64 & 64 \\
\hline 1 & $64.0 \pm 1.2$ & $63.4 \pm 0.7$ & $64.6 \pm 0.8$ & 1 & $63.4 \pm 1.8$ & $61.2 \pm 0.3$ & $62.6 \pm 0.7$ \\
\hline 2 & $63.4 \pm 0.9$ & $61.4 \pm 0.6$ & $62.7 \pm 0.9$ & 2 & $56.1 \pm 0.2$ & $51.3 \pm 0.4$ & $53.0 \pm 0.5$ \\
\hline 3 & $62.7 \pm 2.1$ & $62.1 \pm 1.2$ & $62.1 \pm 0.7$ & 3 & $50.0 \pm 0.8$ & $53.2 \pm 0.7$ & $52.3 \pm 0.5$ \\
\hline 4 & $62.7 \pm 1.3$ & $61.4 \pm 2.1$ & $61.4 \pm 1.3$ & 4 & $49.8 \pm 0.5$ & $50.7 \pm 0.3$ & $53.1 \pm 0.4$ \\
\hline 8 & $61.4 \pm 1.6$ & $61.4 \pm 1.0$ & $62.1 \pm 1.6$ & 7 & $39.2 \pm 1.0$ & $42.7 \pm 0.2$ & $47.7 \pm 0.3$ \\
\hline 10 & $62.1 \pm 2.2$ & $60.8 \pm 2.1$ & $60.8 \pm 2.3$ & 8 & $33.5 \pm 1.7$ & $41.1 \pm 0.5$ & $52.5 \pm 0.5$ \\
\hline 14 & $62.1 \pm 1.4$ & $62.1 \pm 1.5$ & $60.8 \pm 1.5$ & 9 & - & $37.5 \pm 0.3$ & $48.0 \pm 0.2$ \\
\hline 15 & $62.7 \pm 1.1$ & $60.8 \pm 1.4$ & $61.4 \pm 2.2$ & 10 & - & $29.1 \pm 0.8$ & $36.6 \pm 0.9$ \\
\hline
\end{tabular}

*Mean \pm standard deviation $(n=3)$

aliquot parts, stored in eppendorf tubes and frozen until each analysis day. All the procedures were done under aseptic conditions and using sterile drug solutions.

\section{Physical stability study}

The physical stability of the samples was assessed by visual examination during all studied days for colour change and/or precipitation.

\section{Chemical stability study}

Mixtures concentrations were determined by a stability-indicating HPLC method. HPLC analysis was performed at room temperature $\left(\sim 25^{\circ} \mathrm{C}\right)$ using a Shimadzu LC-6A pump equipped with Rheodine 7125 injection valve $20 \mu \mathrm{L}$, a Shimadzu SPD-6A spectrophotometric detector working at $235 \mathrm{~nm}$. The signal from the detector was recorder and integrated with a chromatography data system Shimadzu C-R6A chromatopac; a LiChrospher ${ }^{\circledR} 100$ C18 (5 $\left.\mu \mathrm{m}\right)$ LiChroCART ${ }^{\circledR}$ 250-4 column was employed. The mobile phase consisted of acetonitrile: water $(40: 60, \mathrm{v} / \mathrm{v})$ delivered at flow rate of $1.0 \mathrm{~mL} /$ min. The sample injection volume was $20 \mu \mathrm{L}$, and trip- licate injections were performed for every sample. The initial concentration of mixture was defined as $100 \%$, and subsequent sample concentrations were expressed as a percentage of the initial concentration. Stability of the mixture was defined as retention of at least $95 \%$ of the initial mixture concentration.

\section{Forced degradation analysis}

Forced degradation is a degradation of new drug substance and drug product at conditions more severe than accelerated conditions. It is required to demonstrate specificity of stability indicating methods and also provides an insight into degradation path ways and degradation products of the drug substance. ${ }^{12-13}$

In this work, six different studies were carried out for this purpose over the mixture solution: acid, base, heat, UV light, hydrogen peroxide and sodium hypochlorite.

\section{Compatibility and stability studies}

The compatibility and stability studies were performed at $25 \pm 0.5^{\circ} \mathrm{C}$ and $37 \pm 0.5^{\circ} \mathrm{C}$, and all drug mixtures were 


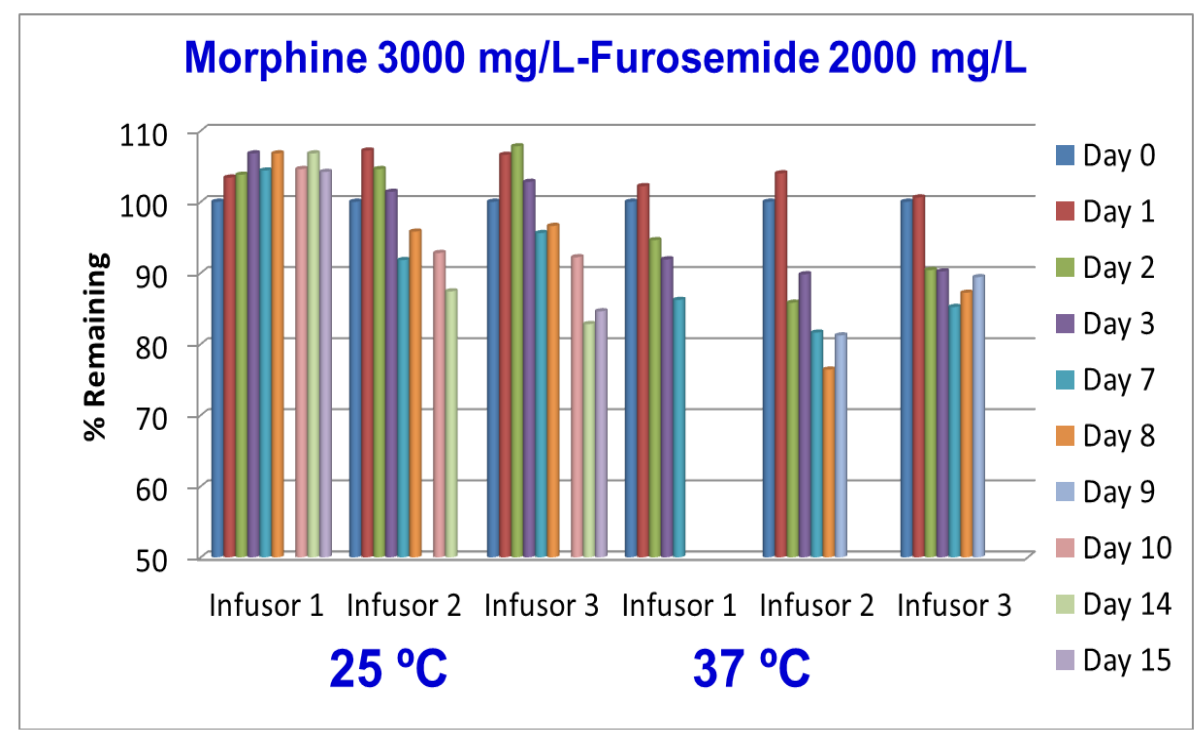

Figure 1: Percentages of morphine-furosemide mixtures $(3000 \mathrm{mg} / \mathrm{L}-2000 \mathrm{mg} / \mathrm{L})$ remaining at $25^{\circ} \mathrm{C}$ and $37^{\circ} \mathrm{C}$

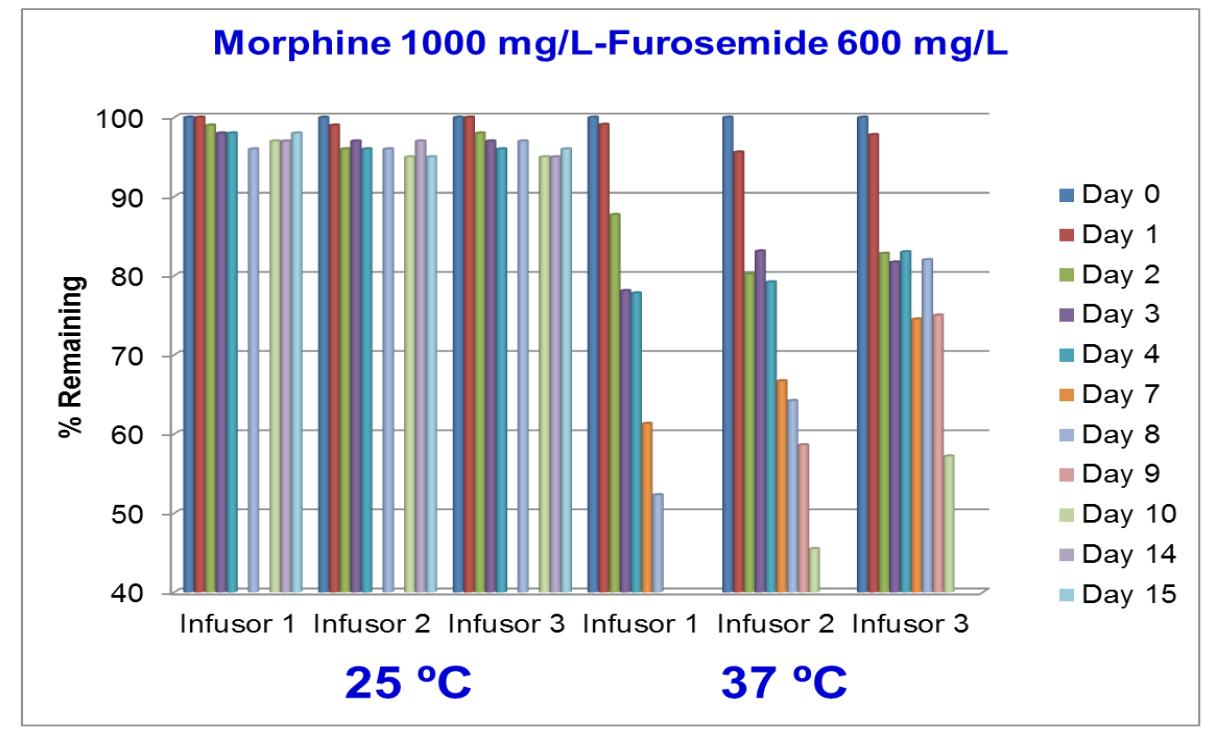

Figure 2: Percentages of morphine-furosemide mixtures $(1000 \mathrm{mg} / \mathrm{L}-600 \mathrm{mg} / \mathrm{L})$ remaining at $25^{\circ} \mathrm{C}$ and $37^{\circ} \mathrm{C}$

protected from direct light exposure. All solutions were assayed in triplicate with four replicates in each case. At pre-determined times-that is $0,1,2,3,7,8,9,10,14,15$ days-the samples were examined for any development and/or change in colour. Also, the drug mixtures were examined for signs of precipitation or cloudiness (turbidity) and gas production under bright light against a dark background.

\begin{tabular}{|c|c|c|}
\hline \multirow{2}{*}{ Table 4: Stability of admixtures } \\
\hline $\begin{array}{c}\text { Morphine- } \\
\text { Furosemide } \\
(\mathrm{mg} / \mathrm{mL}-\mathrm{mg} / \mathrm{mL})\end{array}$ & \multicolumn{2}{|c|}{ Days } \\
\cline { 2 - 3 } & $25^{\circ} \mathrm{C}$ & $37^{\circ} \mathrm{C}$ \\
\hline $3.0 \mathrm{mg} / \mathrm{mL}-2.0 \mathrm{mg} / \mathrm{mL}$ & 8 & 2 \\
\hline $1.0 \mathrm{mg} / \mathrm{mL}-0.6 \mathrm{mg} / \mathrm{mL}$ & 30 & 2 \\
\hline
\end{tabular}

\section{RESULTS AND DISCUSSION}

\section{Accelerated degradation study}

The subsequent studies were made over mixture solutions containing $40 \mathrm{mg} / \mathrm{L}$ of morphine and $24 \mathrm{mg} / \mathrm{L}$ of furosemide.

\section{pH study}

To aliquots of $500 \mu \mathrm{L}$ of mixture were added different amounts of $\mathrm{HCl}$ or $\mathrm{NaOH}(0.1 \mathrm{M}$ and $1 \mathrm{M})(100,200$, 300,500 of both concentration).Additions of $\mathrm{HCl}$ or $\mathrm{NaOH}$ have not influence about the chromatographic signal. The area diminishes by effect dilution when the amount of degradant is higher and also the signal is constant with the time. 


\section{Heat study}

Three samples of mixture solutions were heated at different temperatures $\left(40^{\circ} \mathrm{C}, 60^{\circ} \mathrm{C}, 80^{\circ} \mathrm{C}\right)$ during different times (from 5 to 60 minutes). No significant changes were observed in the chromatograms in all cases.

\section{UV light}

A mixture solution was subject to UV irradiation during several days. After one day under UV radiation, the signal of the admixture diminishes and also colour change is observed into glass.

\section{Oxidants}

To aliquots of $500 \mu \mathrm{l}$ of mixture were added different amounts of $\mathrm{NaClO} 0.2 \mathrm{M}$ and $2 \mathrm{M}$ or $\mathrm{H}_{2} \mathrm{O}_{2} 0.03 \%, 0.3$ and $3 \%(100,200,300,500 \mu \mathrm{l}$ of each reagent and concentration). No effects were observed when the concentration of reagents were lower. The chromatographic signal increases and also stays constant with the time when $0.3 \%$ and $3 \% \mathrm{ofH}_{2} \mathrm{O}_{2}$ were used.

\section{Physical stability study}

All solutions were initially clear and colourless and remained so for the duration of the study. Visible particles appear into the infusers at the same time decreased the concentration of the admixture stored into they.

\section{Statistical evaluation of data}

Calibration curves were linear over the concentration range used with good correlation coefficients. Statistical evaluations of data for different stability studies are presented in Table 1 for each mixture.

\section{Chemical stability study}

All the physically stable solutions were chromatographied. The experimental data were processed making use of the Statgraphics Centurion XVI program. The linearity of the method was evaluated at 5 concentration levels injected by quadruplicate varying from $25 \mathrm{mg} / \mathrm{L}$ to $160 \mathrm{mg} / \mathrm{L}$. The standard calibration curves exhibited good linearity over the range of concentrations tested, with correlation coefficients greater than 0.999 in all cases. The concentrations obtained for each mixture at two studied temperatures $\left(25^{\circ} \mathrm{C}\right.$ and $\left.37^{\circ} \mathrm{C}\right)$ are shown in tables 2 and 3 . The percentages remaining corresponding to different mixtures are shown in figures 1 and 2.

\section{CONCLUSION}

This study was proven to be suitable for determining the stability and compatibility of morphine and furosemide mixtures in elastomeric infusors. It may be applied to stablish the stability of different samples prepared in $\mathrm{NaCl} 0.9 \%$ and stored at two temperatures and can be used in palliative care (Table 4). It can be prepared in advance and stored at room temperature for at least 8 days, but the infusion with a system worn close to a patient that may reach a temperature closer to $37^{\circ} \mathrm{C}$ cannot be longer than two days for both concentrations.

\section{ACKNOWLEDGEMENTS}

The authors thanks to Consejería de Igualdad Salud y Políticas Sociales(Junta de Andalucía) for supporting this study (PI-0013-2013).

\section{SUMMARY}

- Mixture of Morphine-Furosemide $(3.0 \mathrm{mg} / \mathrm{mL}-2.0 \mathrm{mg} / \mathrm{mL})$ is stable eight days at $25^{\circ} \mathrm{C}$ and two day at $37^{\circ} \mathrm{C}$

- Mixture of Morphine-Furosemide $(1.0 \mathrm{mg} / \mathrm{mL}-0.6 \mathrm{mg} / \mathrm{mL})$ is stable thirty days at $25^{\circ} \mathrm{C}$ and two day at $37^{\circ} \mathrm{C}$

\section{About Authors}

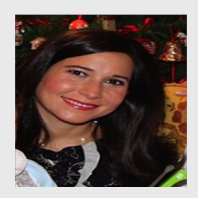

Espinosa Bosch Maria was resident in the pharmacy of the UniversitaryHospital Virgen del Rocio in Seville, Spain. During her training, she obtained a Bachelor's Degree in Health Applied Statistics at UniversityAutónoma of Barcelona. Actually she is working in the UGC Pharmacy in Regional Universitary Hospital of Málaga. Principal investigator of the project obtained in public call from the Junta of Andalucia, Spain for to study the compatibility and stability of different mixtures of drugs and its use in palliative care.
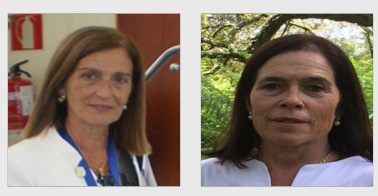

Sánchez Rojas Fuensanta and Bosch Ojeda Catalina, both professor of Analytical Chemistry in the University of Málaga, andthey teach in different degrees (Chemistry, Environment, Chemistry Engineer) and the same time, they are investigators in the study by HPLC of the stability of drugs mixtures in different condition of storage and concentrations. They have some review papers about the determinations of different drugs. 


\section{REFERENCES}

1. WHO Definition of Palliative Care. World Health Organization. Retrieved; 2012 March 16.

2. Schrijvers D, Tai-Apin C, De Smet MC, et al. Determination of compatibility and stability of drugs used in palliative care. J Clin Pharm Ther. 1998; 23(4): 311-14.

3. Zachrisson U, Furst CJ. Drug infusers in palliative medicine: a Swedish inquiry. Journal of Pain Symptom Manage 1998; 15(5): 299-304.

4. Bruera E, Brenneis C, Michaud M, et al. Use of the subcutaneous route for the administration of narcotics in patients with cancer pain. Cancer 1988; 62(2): 407-11.

5. Storey $\mathrm{P}$, Herbert $\mathrm{HH}$, St Louis $\mathrm{RH}$, et al. Subcutaneous infusions for control of cancer symptoms. Journal of Pain Symptom Manage 1990; 5(1): 33-41.

6. Vigneron J. Stability studies of drugs used in oncology: The role of the hospital pharmacist. Eur J Hosp Pharm Pract. 2006; 12(6): 75-6.

7. Barcia E, Reyes R, Azuara ML, et al. Compatibility of haloperidol and hyoscine-N-butyl bromide in mixtures for subcutaneous infusion to cancer patients in palliative care. Support Care Cancer 2003; 11(2): 107-13.
8. Good PD, Schneider JJ, Ravenscroft PJ. The compatibility and stability of midazolam and dexamethaxone in infusion solutions. Journal of Pain Sympton Management 2004; 27(5): 471-5.

9. Barcia E, Reyes R, Azuara ML, et al. Stability and compatibility of binary mixtures of morphine hydrochloride with hyoscine-N-butyl bromide. Support Care Cancer 2005; 13(4): 239-45.

10. Negro S, Reyes R, Azuara ML, et al. Morphine, haloperidol and hyoscine $\mathrm{N}$-butyl bromide combined in s.c. infusion solutions: Compatibility and stability. Evaluation in terminal oncology patients. Inter J Pharma. 2006; 307(2): 278-84

11. Negro S, Salama A, Sánchez $\mathrm{Y}$, et al. Compatibility and stability of tramadol and dexametaxone in solution and its use in terminally ill patients. J Clin Pharm Ther. 2007; 32(5): 441-4.

12. Singh $\mathrm{S}$, Junwal $\mathrm{M}$, Modhe $\mathrm{G}$, et al. Forced degradation studies to assess the stability of drugs and products. Trends Anal Chem. 2013; 49(1): 71-88.

13. Blessy M, Patel RD, Prajapati PN, et al. Development of forced degradation and stability indicating studies of drugs-A review. J Pharm Anal. 2014; 4(3): 159-65. 